\title{
Extraction of Eucalyptus Oil as Reduction of Bacterial Growth in Drinking Water
}

\author{
Ashwani Kumar Dubey, Omprakash Sahu* \\ Department of Chemical Engineering, KIT Jamnagar, Gujarat, India \\ *Tel: +919752610957 \\ *E-mail address: ops0121@gmail.com
}

\begin{abstract}
Drinking water is acting as life line for living thing on the Earth, without that no life. Due to global industrialization availability of pure water is one of the major issues. The effluent are directly or indirectly discharge through the river stream, which affect the ground as well as sea water and climatically cycle water reach to us. In that condition medicine are required for quire purpose. In the world so many plants and herbs are available which are used as antimicrobial and sources of medicines. Today the large number of drugs in use is derived from plants. The important advantages for therapeutic uses of medicinal plants in various ailments are their safety besides being economical, effective and easy availability. In this regard's herb plant Eucalyptus extracted oil is used as antibacterial agent to treat the drinking water.
\end{abstract}

Keywords: Bacterial; Composition; Essential oil; Growth rate; Microbes

\section{INTRODUCTION}

In World large numbers of aromatic and medicated plants are available in most of the region. In which Eucalyptus plant is most common among them. Eucalyptus is recognized today as a natural product which has much to offer in solving global agricultural, environmental and public health problems. Researchers worldwide are now focusing on the importance of neem in the agricultural industry [1].

The magical tree and hundreds of its active compounds are used to manufacture a number of products. Natural properties of eucalyptus do not have any toxic reactions, so they are helpful in plant protection and management. All the parts of plant like seed, flowers, bark, and leaf can be used to produce high quality product [2].

The Eucalyptus leaves have available in light green color on tall straight tree the picture is shown in Fig. 1. 


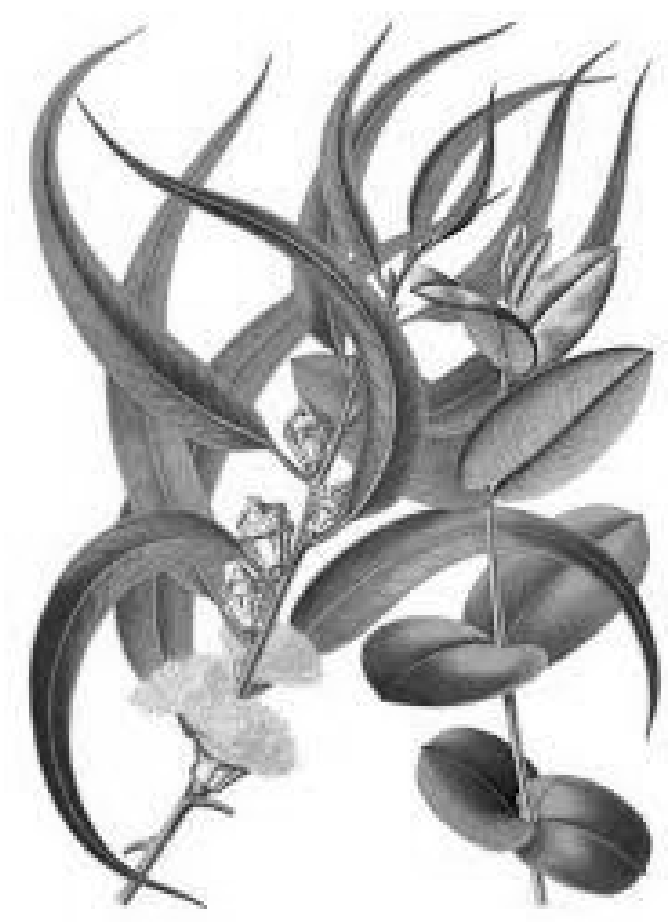

Fig. 1. Eucalyptus Leaves (E. citriodora).

The essential oil extract from the Eucalyptus leaves which contain compounds with an extremely broad range of biochemical effects as well as odor, flavor and functional properties. Antimicrobial, analgesic and anti-inflammatory properties of E. citriodora, E. globulus and E. teretcorni have been reported from different parts of the world $[3,4]$. The leaves of E. citriodora contain about $1.36 \%$ essential oil that is predominately citronellal (57\%) followed by citronellol $(15.89 \%)$, citronellyl acetate $(15.33 \%)$ and other compounds $[5,6]$. This essential oil showed a wide spectrum of antimicrobial [7-10], antifungal [11,12], anticandidal [13] antibacterial $[14,15]$ expectorant and cough stimulant activity [16]. Due to its disinfectant action, the essential oil is used externally, applied to cuts and skin infections but it has deleterious effect on the body in high doses [17,18]. Beside antimicrobial activity, the essential oil and its constituents have also been used for their herbicidal [19,20], insecticidal $[21,22]$ antihelmintic [23], anti-tumour [24] and anti-leech [25,26] properties, as well as in integrated disease management against phytopathogenic fungi nonspecific skin infections and mastitis in animals [27,28].

Drinking water is considered to be life line for living organism on the earth. If the life line disturb the life is to be disturb. Generally due high cost of treatment or purification makes the drinking water costly. In the rural area or low income community people directly feed the raw water it cause infection or diseases. The applications of low-cost treatment obtained from plant are replacement for costly conventional methods for removing the microbial in drinking water. Eucalyptuses are available in almost all part of the world and in literature Eucalyptus are used as adsorbent or wastewater treatment material. Even for heavy metal ion up to toxic material [29]. In this regard's some alternatively and low cost treatment is try to introduce for treatment of drinking water. In this work extracted oil from Eucalyptus leaves are apply on the municipal drinking water supply. 


\section{MATERIAL AND METHODS}

\section{1. Material}

The Eucalyptus leaves are arranged from university campus. The leaves are dried for 7 days or the leaves falls down automatically are collected. It was crush manually with wooden arrangement and make in powder form, which shown in Fig. 2.

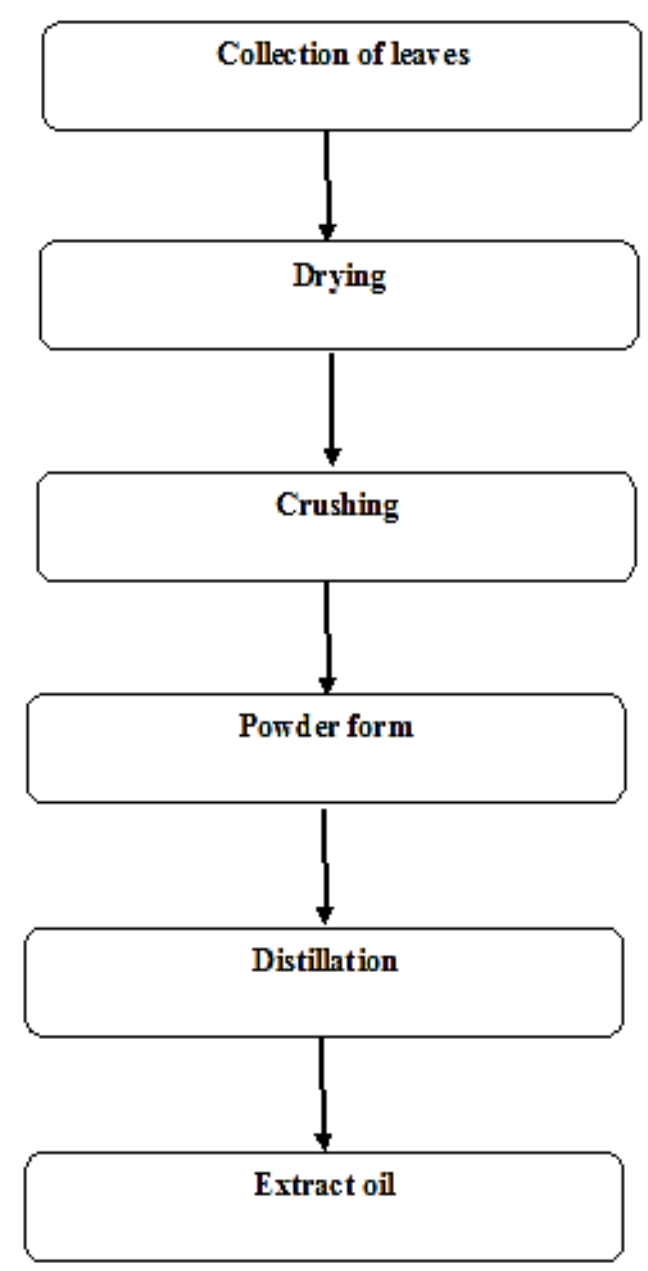

Fig. 2. Steps for making the extract oil from leaves.

\section{2. Method}

Extraction of oil was carried out by soxhlet apparatus and it's working on steam distillation process. The powdered leaves of $50 \mathrm{gm}$ were added on $400 \mathrm{ml}$. of water, the working temperature was maintained at $100{ }^{\circ} \mathrm{C}$ and distillated for 1 hour. Once the distillation started the sample start boiling within $5 \mathrm{~min}$ and vapour are formed. The vapour is cooled down with the help of condensed. The condensed material was collected on the other side of setup. The collected material is a mixture of oil and water. After the water was separated by the rotary evaporator, the Eucalyptus oil was purified, which used as antibiotic material for drinking water. 


\section{3. Estimation of microorganism}

The original in oculum is diluted in a series of dilutions. Each succeeding dilution will have only one-tenth the numbers of microbial cells as the preceding tube. Then the samples of the dilution samples are used to inoculate (spread plate) the Petri plate on which the colonies grow and can be counted. The water sample containing bacteria $(E$. coli) are streaked on to the Nutrient Agar medium to check the growth of bacteria. The water sample was used as a control. If there were no colonies on the medium, the results indicate that the Disinfectant is highly effective against the bacteria. All the treatments were carried out in triplicates and the average values were accounted.

\section{4. Quality analysis of extracted oil}

The major test was to know the percentage of 1,8-cineole. The essential oils were analyzed by GC/MS where the composition of the ten commonly found compounds in the oils were as follows by similar study in Tigray region on the same species: 1,8 -cineole $(66.28$ - $75.36 \%)$, cis-ocimen $(15.92-21.33 \%), \alpha$-terpineol acetate $(2.70-3.39 \%)$, $\alpha$-terpineol $(1.51-2.26 \%)$, aromadendrene (0.69 - $2.85 \%)$, globulol $(0.82-1.43 \%)$, $\beta$-pinen $(0.96-1.24$ $\%), \beta$-myrcene $(0.66-1.00 \%)$, 4-terpineol $(0.46-0.52 \%)$ and camphene $(0.16-0.27 \%)$ as the main leaf oil components. The oils could be used for medicinal purpose if 1,8 -cineole content is greater than $70 \%$ otherwise the oil needs purification and enrichment so as to make its 1,8-cineole content greater than $70 \%$. The study is shown in Fig. 3.

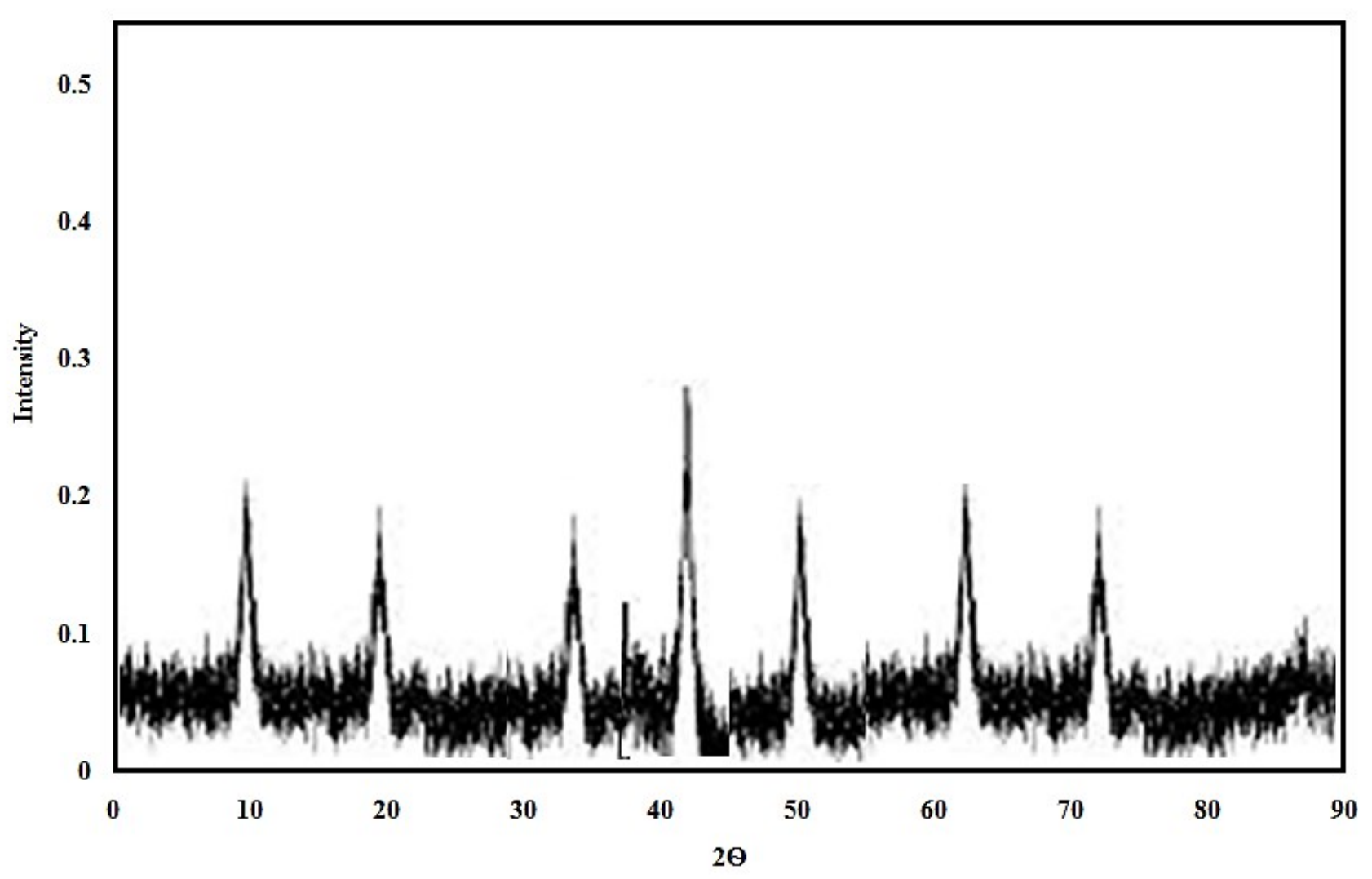

Fig. 3. Chromatographic study of extracted oil. 


\section{RESULT AND DISCUSSION}

\section{1. Extraction of oil}

\section{1. 1. Optimization of temperature}

Volume of essential oil obtained from a plant material was different for different temperatures and at a particular temperature for different time of heating. Volume of essential oil obtained is less in comparison to hydrosol of the same plant material. Its variation along with temperature and time of heating is shown in Fig. 4.

It was observe that volume of essential oil obtained from eucalyptus is almost increasing linearly with temperature. The maximum extracted oil was $0.5 \mathrm{ml}$ at $120^{\circ} \mathrm{C}$. After $100^{\circ} \mathrm{C}$ the extract oil are shown constant decline.

The decline may be due to leakage of vapor during steam distillation or because of improper decantation. Less than $100{ }^{\circ} \mathrm{C}$ the essential oil extract less or negligible before the components of the oil reach to their boiling point.

After reaching to their boiling points essential oil is obtained and further, it can speculate that if increase more temperature proliferation in volume can be achieved.

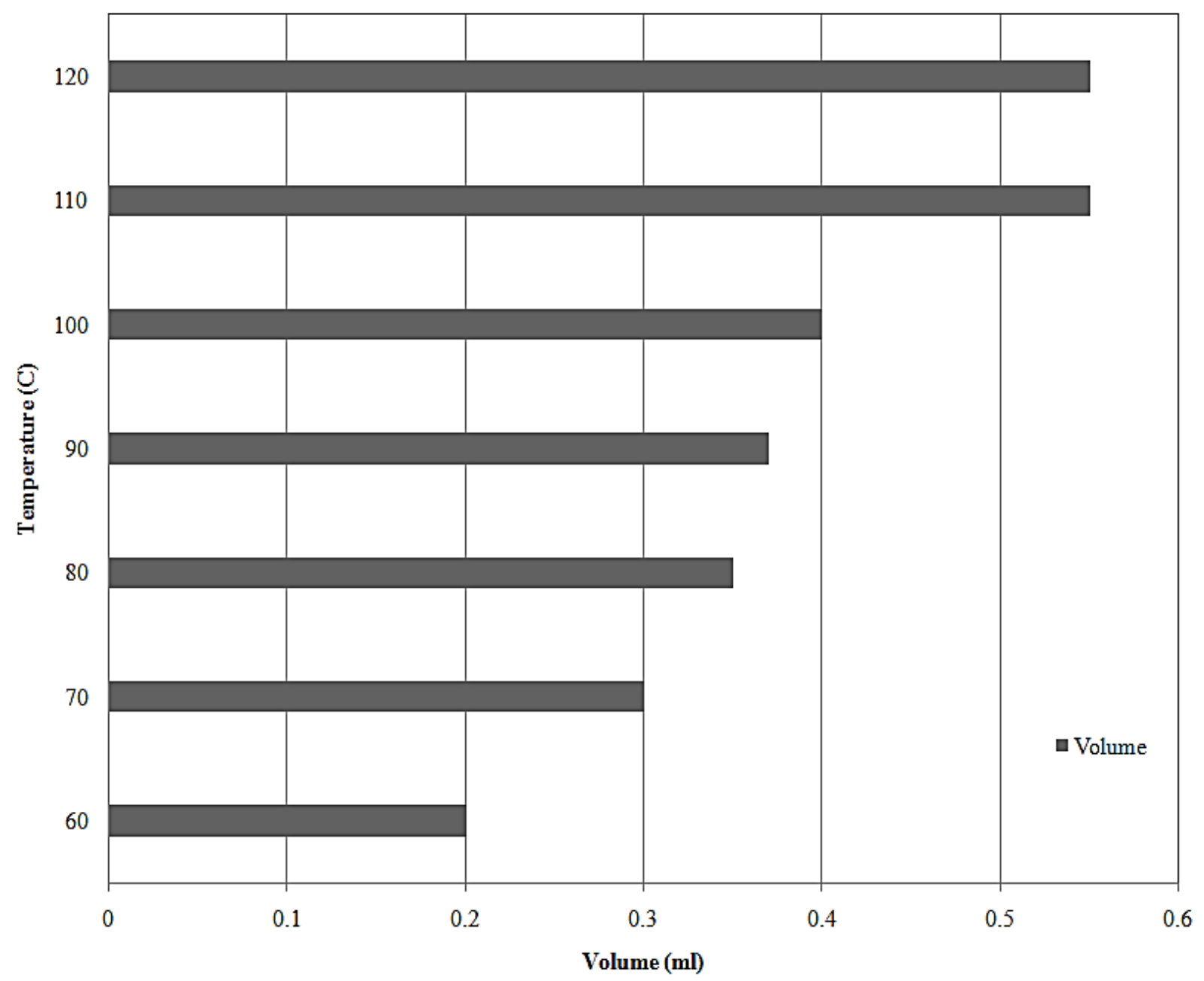

Fig. 4. Effect of temperature on extraction of oil. 


\section{1. 2. Optimization of time}

Volume of essential oil obtained from a plant material was different for different temperatures. The experiment was carried out at $100{ }^{\circ} \mathrm{C}$, which is shown in Fig. 5. It was observed that volume of extraction oil increase with increase in time.

From that it was found that volume increase linearly with time and then it became constant. At $100 \mathrm{~min}$ of experiment extract oil was $0.4 \mathrm{ml}$ when time increase again the extraction of oil was constant. It may be due to the temperature supplied was not sufficient to vaporize the components of oils.

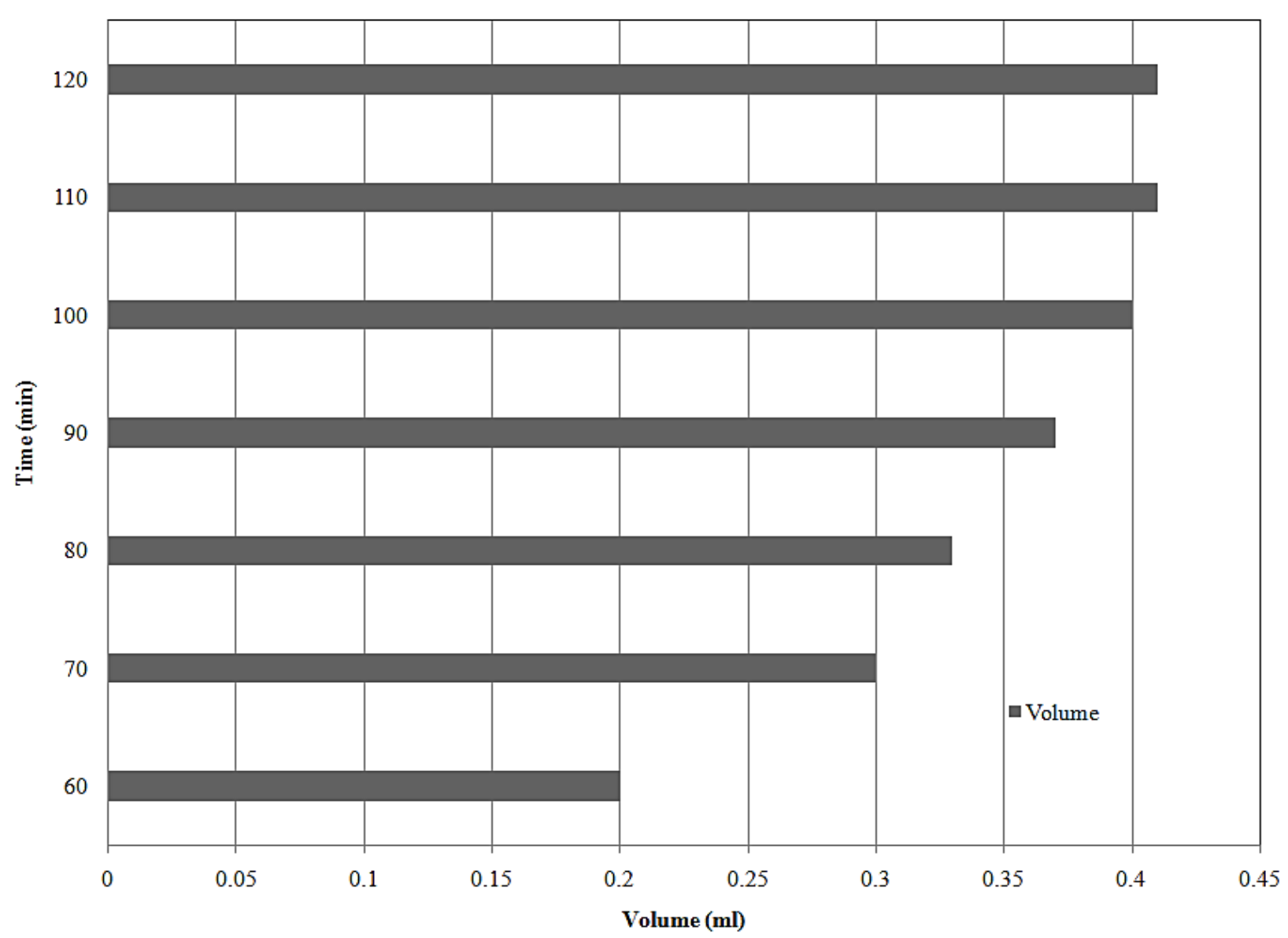

Fig. 5. Effect of time on extraction of oil.

\section{2. Treatment of drinking water}

\section{2. 1. Optimization of $\mathbf{p H}$}

The effect of $\mathrm{pH}$ on drinking water was carried out 2 hours at $2 \mathrm{ml} / 1$ of extracted oil, which is shown in Fig. 6. It was found that maximum microbial reduction $13 \%$ was occurred at $\mathrm{pH}$ 7. The microbial reduction decrease $11 \%$ and $10 \%$ when $\mathrm{pH}$ increases 7.05 and 7.1, when $\mathrm{pH}$ was 6.9 and 6.95 the microbial reduction was 12 and $11 \% \mathrm{pH}$ is one of the important biotic factors that serve as an index for pollution. 
The factors like photosynthetic exposure to air, disposal of industrial water and domestic sewage effect $\mathrm{pH}$ is the value expressed as the negative logarithm of the hydrogen ion concentration. Its range are given between 0 to 14.7 being neutral less than 7 being acidic and above 7 being basic or alkaline.

The wide narration in the $\mathrm{pH}$ value of effluent can affect the rate of biological reaction and survival of various microorganisms. The presence or absence of various ionic specials can have direct relation with $\mathrm{pH}$ of the water. Subsequently, such water can influence the quality of soil. The reaction between water flowing from an open drainage system in the soil has direct relevance to the $\mathrm{pH}$ effluent. It is therefore, necessary to evaluate effluent with respect to the $\mathrm{pH}$ value.

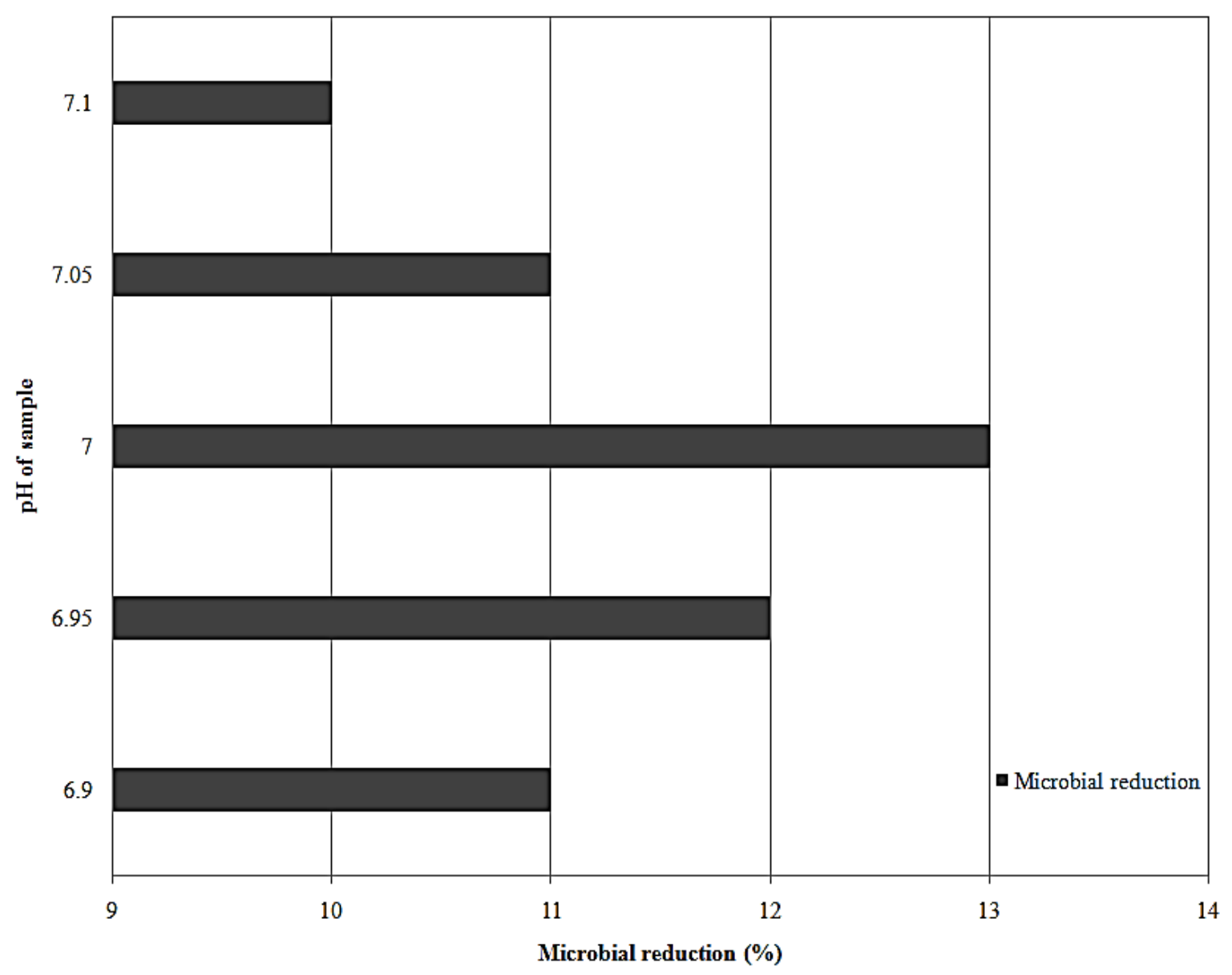

Fig. 6. Effect of $\mathrm{pH}$ on microbial reduction.

\section{2. 2. Optimization of time}

The effect of time on microbial reduction was carried out at $4 \mathrm{ml} / 1$ dosing and sample $\mathrm{pH}$ 7, which is shown Fig.7. It was observed that microbial reduction was increase linearly with time. The maximum microbial reduction was $97 \%$ at 12 hours of treatment. When the experimental time was $1,2,3,4,5,6,7,8,9,10$ and 11 hours the microbial reduction 15, 28, $38,47,56,63,72,79,85,88$ and $94 \%$ respectively. Time is another important parameter for the treatment, in less time extract oil may be not effective for the microbial growth. 


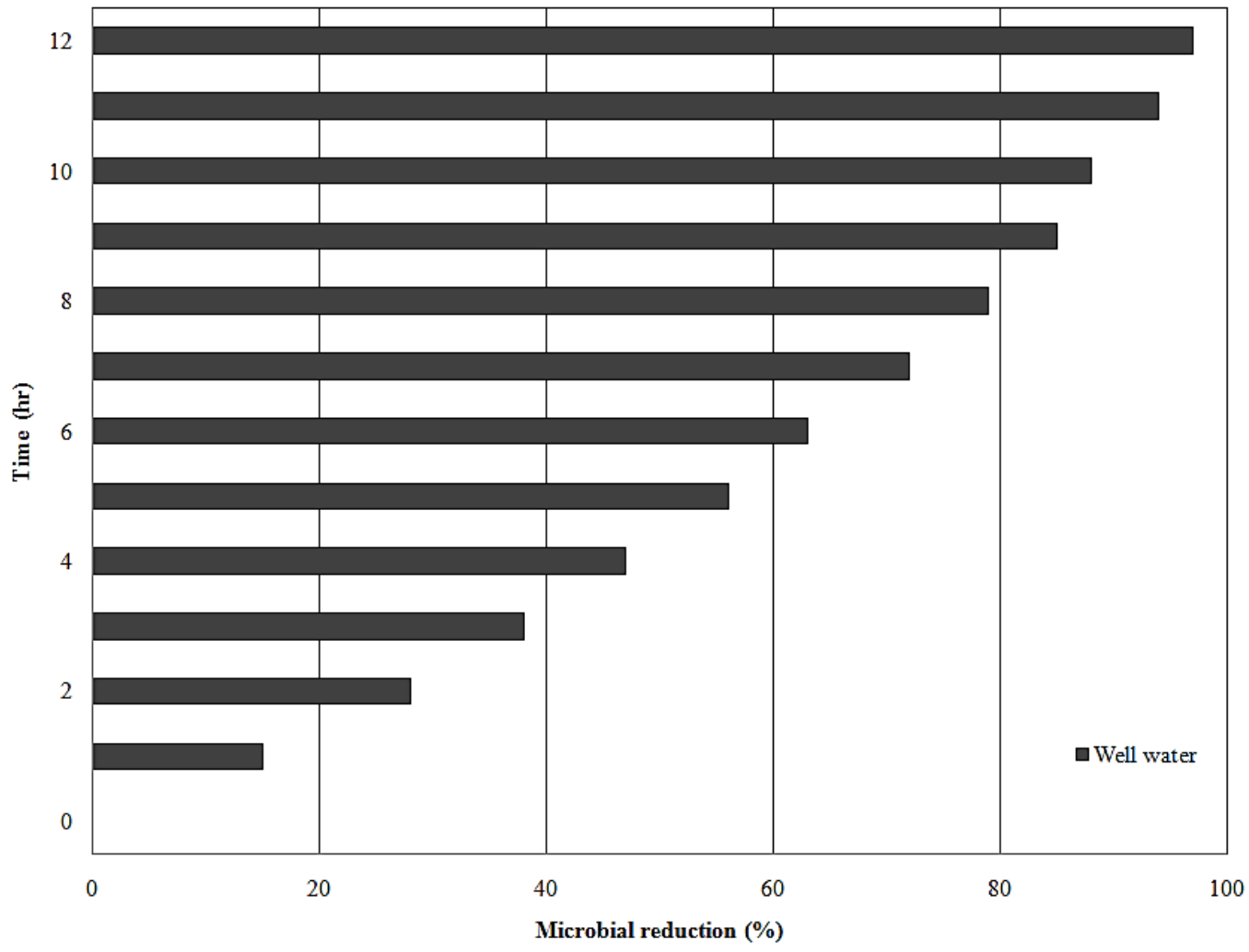

Fig. 7. Effect of time on microbial reduction.

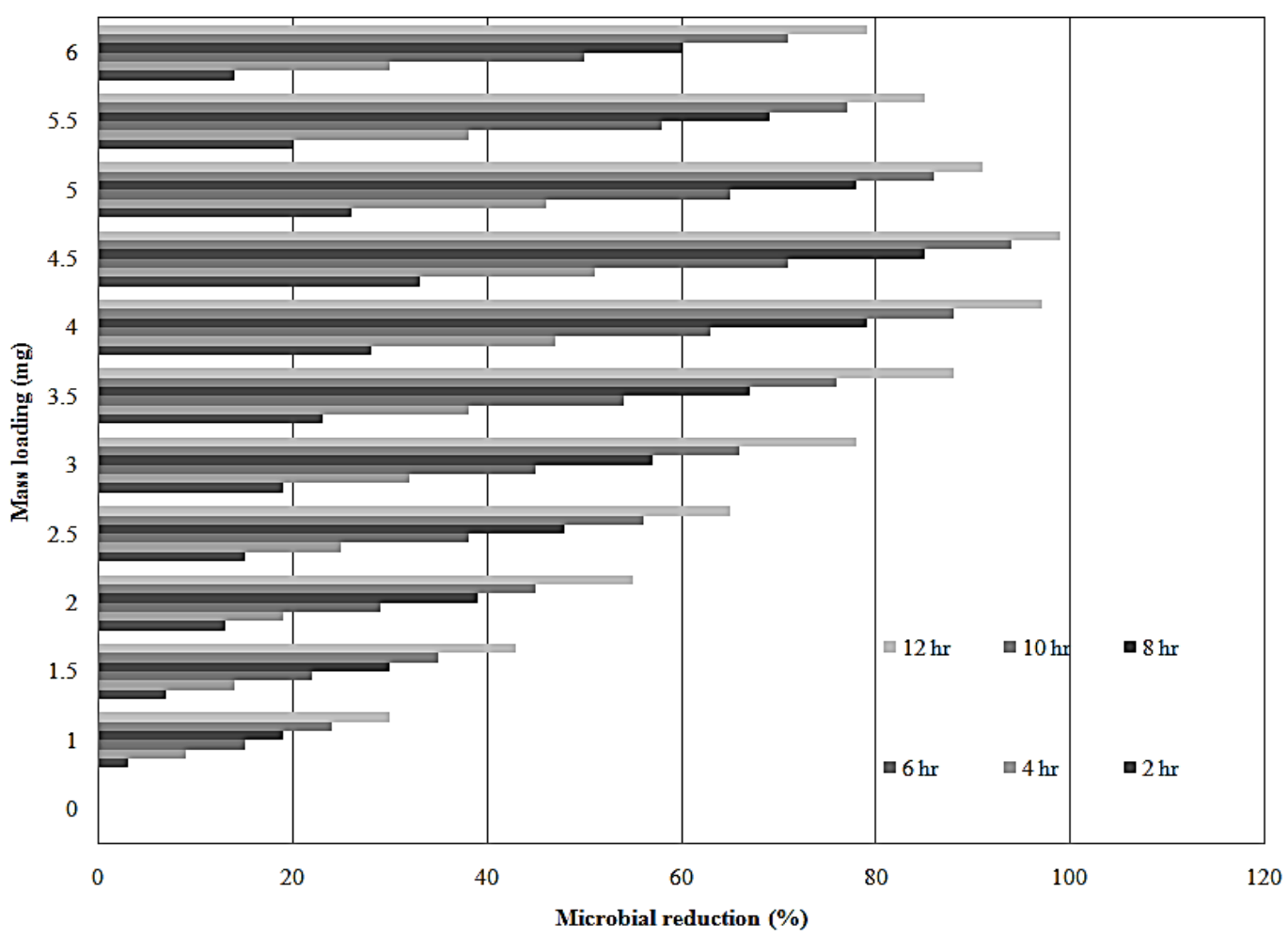

Fig. 8. Effect of mass loading on microbial reduction. 


\section{2. 3. Optimization of mass loading}

The effect of mass loading was carried out at 12 hours of experimental time at $\mathrm{pH} 7$, which is shown in Fig. 8. It was observed that when dosing was increase from $1 \mathrm{ml} / 1$ to 4.5 $\mathrm{ml} / 1$ the microbial reduction was increase sharply from $30 \%$ to $99 \%$, after increase in dosing $5 \mathrm{ml} / 1$ to $6 \mathrm{ml} / 1$ the microbial reduction was decrease with $91 \%$ to $79 \%$ respectively. The optimum dose plays optimum effect to control the bacterial growth. Excess dosing or less dosing was not sufficient to control the bacterial growth.

\section{CONCLUSION}

This research show that eucalyptus extract oil has effective property to reduced the microbes present in the drinking water. Extract oil containing bioactive compounds with an extremely broad range of biochemical effects with essence of odor and flavor. Soxhlet distillation method was found to be one of the promising techniques for the extraction of essential oil from plants as reputable distiller will preserve the original qualities of the plant. Volume $0.4 \mathrm{ml}$ of essential oil was obtained at $100{ }^{\circ} \mathrm{C}$ of heating temperature in $100 \mathrm{~min}$ of heating time, which means it depends upon the temperature and time of heating. With maximum 12 hours of treatment time at $4.5 \mathrm{ml} / 1$ of dosing are effective to reduced $99 \%$ of microbial in drinking water. Eucalyptus not only treat the drinking water but it also protect from infection and disease which is generally due to water.

\section{Reference}

[1] Pant Chaitanya, Thomas J. Sferra, Abhishek Deshpande, Anil Minocha, European Journal of Internal Medicine 7 (2011) 210-222.

[2] Pollack A., Rising Threat for Infections Unfazed by Antibiotics. The New York Times, February 27 (2010) B1.

[3] Ramezani H., Singh H. P, Batish D. R. O., Kohli R. K. Antifungal, Fitoterapia 73 (2002) 261-262.

[4] Silva J., Abebe W., Sousa S. M., Duarte V. G., Machado MIL, J. Ethnopharmacol. 89 (2003) 277-83.

[5] Chalchat J. C., Muhayimana A., Habimana J. B., Chabard J. L., J Essent Oil Res. 9(2) (1997) 159-65.

[6] Tian Y., Liu X., Zhou Y., Guo Z., Chinese J Chromatography 23(6) (2005) 651-54.

[7] Dellacassa E, Menendez P, Moyna P, Cerdeiras, Fitoterapia 60(6) (1989) 544-546.

[8] Hmamouchi M., Elarakas A., Eantoui A., Sati N. E., Plantes Med Phytother. 24(4) (1990) 278-89.

[9] Hajji F., Tetouani S. F., Tantaui E. A., Fitoterapia 64(1) (1993) 71-77.

[10] Changriha N., Cherif Y. F., Baailouamer A., Meklati B. Y., Rivista Italiana EPPOS 25 (1998) 11-16.

[11] Ramsewak R. S,, Nair M. G., Stommel M., Selanders L., Phytother Res. 17(4) (2003) 376-379. 
[12] Ramezani H., Common Agric Appl Bio Sci. 71(3B) (2006) 909-994.

[13] Dutta B. K., Karmakar S., Naglot A., Aich J. C., Begam M., Mycoses 50(2) (2007) 12124.

[14] Low D., Rawal B. D., Griffin W. J., Planta Med. 26(2) (1974) 184-189.

[15] Cimanga K. et al., J Ethnopharmacol. 79(2) (2002) 213-220.

[16] Oyedeji A. O., Ekundayo O., Olawore O. N., Adeniyi B. A., Koenig W. A., Fitoterapia 70(5) (1999) 526-528.

[17] Whitman B. W., Ghazizadeh H., J Paediatr Child Health 30(2) (1994) 190-191.

[18] Tibballs J., Med J Aust. 163(4) (1995) 177-180.

[19] Batish D. R, Singh H. P., Setia N., Kaur S., Kohli R. K., Z Naturforsch 61(78) (2006) 465-471.

[20] Setia N., Batish D. R., Singh H. P, Kohli R. K., Ther Umsch. 62(11) (2005) 713-718.

[21] Park I. K., Shin S. C., J Agric Food Chem. 153(11) (2005) 4388-4392.

[22] Bennet J. E., Bryant C., Int J Parasitol. 26(8/9) (1996) 937-047.

[23] Takasaki M., Konoshima T., Kozuka M., Tokuda H., Biol Pharm Bull. 18(3) (1995) 435-38.

[24] Kirton L. G., Ann Trop Med Parasitol. 99(7) (2005) 695-714.

[25] Agarwal A. K., Indian Veterinary J. 74(5) (1997) 417-419.

[26] Joshi H. C., Kumar M., Saxena M. J., Chhabra M. B., Indian J Dairy Sci. 49(9) (1996) 631-634.

[27] Pavneesh M., Pandey S. K., Chhabra M. B., Saxena M. J., Int J Animal Sci. 11(2) (1996) 289-291.

[28] Gouveia I. C., Journal of Biotechnology (2010) 150-S.

[29] Rosenthal D. V., Dennis G. Maki, Jamulitrat S., Medeiros E. A., American Journal of Infection Control. 4 (2009) 95-104. 